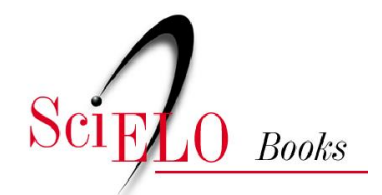

\title{
O humanismo da palavra rabelais e o discurso do homo ridens
}

\author{
Annarita Angelini
}

\section{SciELO Books / SciELO Livros / SciELO Libros}

ANGELINI, A. O humanismo da palavra: rabelais e o discurso do homo ridens. In: PINTO, F.M., and BENEVENUTO, F., comps. Filosofia, política e cosmologia: ensaios sobre o renascimento [online]. São Bernardo do Campo, SP: Editora UFABC, 2017, pp. 227-252. ISBN: 978-85-68576-93-9. https://doi.org/10.7476/9788568576939.0012.

\section{(@) $\stackrel{0}{\mathrm{i}}$}

All the contents of this work, except where otherwise noted, is licensed under a Creative Commons Attribution 4.0 International license.

Todo o conteúdo deste trabalho, exceto quando houver ressalva, é publicado sob a licença Creative Commons Atribição 4.0.

Todo el contenido de esta obra, excepto donde se indique lo contrario, está bajo licencia de la licencia $\underline{\text { Creative }}$ Commons Reconocimento 4.0. 
Doutora em filosofia pela Universidade de Florença e professora de História da Filosofia da Universidade de Bolonha (UNIBO), na Itália. É coordenadora da Licenciatura em Filosofia no Departamento de Filosofia de Bolonha, membro eleito pelo conselho científico de l'Institut des Sciences Humanines et Sociales (CNRS) e membro do conselho científico do Mestrado da Université François Rabelais - Centro de Estudos Superiores da Renascença. É membro do grupo de pesquisa Theta CNRS - Centre UPR 76 Pépin (Paris) e coordenadora italiana do grupo GDRI ESTRELA. É autora de numerosos estudos sobre o humanismo italiano e francês, bem como de vários livros: $L a$ voce del serpente. Modi dela conoscenza simbolica (Bolonha, 2012); Tout le savoir du Monde. Aux origines de l'Encyclopédie moderne (Paris, 2012); e Metodo ed enciclopédia nel Cinquecento francese (Florença, 2008). 


\section{O HUMANISMO DA PALAVRA: RABELAIS E O DISCURSO DO HOMO RIDENS ${ }^{1}$}

Annarita Angelini

Um tema central da civilização do humanismo insiste sobre a relação entre filologia e filosofia, e, mais diretamente, sobre a ligação que conecta entre elas o órgão do pensamento, a ratio, e o órgão da expressão, a oratio.

Uma relação, aquela sobre a qual os humanistas discutem, que descende ela mesma da antiquíssima reflexão em torno da natureza da palavra e dos conceitos e, mais precisamente, da relação que se estabelece entre os signos linguísticos, as noções que veiculam e as coisas as quais se referem. Uma tradição, aquela que se alinha ao humanismo, que retoma

\footnotetext{
${ }^{1}$ Artigo traduzido do italiano para o português pela pesquisadora Talita Janine Juliani, Licenciada em Letras pela Universidade Estadual de Campinas (UNICAMP), Mestre (CAPES) e Doutora (FAPESP) em Linguística (na área de Letras Clássicas) pela mesma instituição.

${ }^{2}$ Professora de História da Filosofia da Universidade de Bolonha (UNIBO), na Itália.
} 
o De interpretatione aristotélico: os sons da voz são símbolos da afeição da alma e as letras escritas são símbolos dos sons da voz, e como as letras não são as mesmas para todos os homens, assim não são iguais nem mesmo os sons. O nome é o som da voz e é significativo por convenção, contudo sons e letras são sinais da afecção da alma, as quais são as mesmas para todos e constituem as imagens de objetos, já idênticos para todos (Int, 16A). Um significado convencional, aquele atribuído por Aristóteles às palavras, as quais remetem aos estados de ânimo constantes, por sua vez imagens de realidade objetivas. Entre a coisa e o conceito de alma existe então uma ligação natural e igual para todos; arbitrários ou ao menos convencionais são os sons articulados e as palavras destinadas, umas e outras, a exprimir estados de ânimo. A alma, com suas afecções, impõe-se como mediadora entre as coisas e as palavras.

A editio princeps do Platão latino, publicada por Ficino em 1484, movimentava o quadro propondo, com Crátilo, três posições diversas entre si, nenhuma das quais reconduzível àquela aristotélica. Dos três interlocutores do diálogo platônico, Hermógenes, simpático à posição de Parmênides, sustenta a tese de uma relação puramente convencional entre os nomes e as coisas que estes são chamados a designar. A ele se opõe o personagem de Crátilo, defensor da posição heraclideana segundo a qual as palavras correspondem "naturalmente" às coisas que nomeiam. Contra a tese de Crátilo, e contra o convencionalismo de Hermógenes, Sócrates afirma que a precisão dos nomes deriva do seu representar alguma coisa do objeto. Os nomes são mimémata (cópias) e o nomóteta que denomina é um imitador; contudo, em analogia com a linguagem visual e com a pintura, a distinção entre os dois tipos de nomes (corretos e incorretos) é determinada pela diferente relação entre 
miméma e parádeigma (entre cópia e modelo). Nomes sofistas ou incorretos, são aqueles que, como phantásmata, reproduzem ilusoriamente uma aparência de realidade determinando um fragor caleidoscópio de vozes. Por outro lado, são "precisos" os nomes univocamente adequados à natureza do referente, os quais, também enquanto cópias, refletem uma proporção definida como alethés (verdadeira) e são atribuídos por um onomatourgos (um artífice de nomes) capaz de nomear as coisas apenas à medida que se conhece a ideia. Não phántasma, portanto, mas eikón, enquanto o aspecto (eídolon) deles foi, por assim dizer, forjado, considerando-se não a coisa como ela aparece aos sentidos, mas aquilo que a coisa é em si mesma ${ }^{3}$.

No início do século XV, o afirmar-se e codificar-se das gramáticas vulgares sobre os espólios de um latim ecumênico, mas reconhecidamente corrupto e bárbaro à prova da filologia humanista, é uma das múltiplas regiões de um pluralismo linguístico defendido, sob a escolta de Valla, por muitos humanistas, contra os apoiadores de uma suposição natural. Enquanto um fato social, necessário à comunicação interpessoal, a língua alcança o próprio significado e a própria adequação da consuetudo loquendi e não da presunção de poder reproduzir a estrutura física, natural ou metafísica do próprio

\footnotetext{
${ }^{3}$ No primeiro caso, sofístico, o nome, a veste linguística, reproduz o modelo assim como aparece à vista, no segundo o reproduz segundo parece à mente (ALLEN, M. J. B., 1978, p. 117-118). Dois gênios, um benigno, o outro, maligno - exemplifica Bocchi -, preenchem o vaso que é a inteligência humana, criando obstáculos um ao outro. O gênio benigno preenche o vaso dos próprios inventa, que são nomes ou ícones de coisas, os quais contém em si a própria ideia da coisa denominada; o outro insinua palavras sofísticas e mentirosas, as quais, em vez de deixar transparecer a verdade, o sentido, a natureza das coisas, a esconde ainda mais. A distinção aqui proposta entre copia e inventum é a mesma que Sócrates determina entre phantasma e eikon, ambas cópias (mimèmata), mas apenas a segunda capaz de refletir uma "porção determinada de verdade".
} 
referente. Daí a admissão de gramáticas diversas, legitimadas por nada além do que seja o consensus hominum, e daí também o caráter histórico das línguas, destinadas a modificar-se ao longo do tempo em razão das mudanças internas ao grupo daqueles que compartilham um código expressivo.

No entanto, o caráter histórico das línguas e a defesa do pluralismo linguístico e gramatical, considerando-se a base sobre a qual se impõem e se codificam as gramáticas vulgares, em nada diminuem a necessidade de uma linguagem filosófica convencionada, à maneira socrática, como organon não de comunicação, mas de conhecimento. Daí a função delótica que muitos filósofos do Renascimento negam à linguagem verbal e às línguas chamadas "históricas", mas que salvaguardam para atribui-la a um código diverso e uma sintaxe diversa, habilitados a desvelar a essência das coisas. Daí ainda a pesquisa, ao lado da gramática de verba e de voces estimadas em razão de seus valores de uso, de uma linguagem simbólica - diferente e superior a toda koiné particular - que se desenvolve em paralelo àquela: uma filologia muda, e mesmo única, verdadeiramente eloquente, a qual não escolhe uma tradição à outra, mas antes tenta construir uma sabedoria universal, não tanto sobre os elementos comuns às diversas tradições, mas sobre a natureza comum dos falantes.

Umberto Eco, em seu Diario minimo, escreveu que Gargantua et Pantagruel de François Rabelais "é um livro que conclui uma época e inicia outra”. É o riso, segundo Eco, que permite ao herói do ciclo rabelaisiano - Panurge - instalar-se dentro da ordem da cultura medieval para miná-la internamente, deformando-lhe a fisionomia. Mas, olhando com atenção, o riso iconoclasta de Panurge e, de forma mais geral, o riso do romance de Rabelais, são o efeito de um discursus que 
acolhe as regras, a linguagem, as palavras, os sons de uma civilização antiga, para conectá-los a um novo e diverso referencial: um homem culto em sua incompleta e imanente humanidade, que se serve de palavras para falar de si e não mais evocar um universo de conceitos sublimes e transcendentes. É a palavra que fala e ri de si mesma e, mais precisamente de um homem, que a pronuncia e a articula para servir-se dela e para falar de si. Do único ser que, ao contrário dos anjos e dos animais, é capaz de rir e de ser ridicularizado.

Também Rabelais é indulgente ao modo da época e, no capítulo 37 do Quarto livro do ciclo de Gargantua et Pantagruel, faz homenagem ao Crátilo platônico e a uma questão de grande destaque na cultura da época. O contexto é aquele da batalha contra os Andouille: Pantagruel se compraz com o prognóstico de Epistemon sobre o bom êxito da batalha a partir dos nomes dos dois comandantes, respectivamente Rifandouille e Tailleboudin. Não é uma nova maneira de fazer prognósticos aquela que reconhece no nomen o omen - adverte Pantagruel - remetendo ao Crátilo do divino Platão tal qual fonte de auctoritas por excelência ${ }^{4}$.

Pantagruel se exibe aqui não em uma defesa genérica da teoria platônica da linguagem, mas em uma forma extrema de cratilismo sustentando o poder dos nomes capazes não só de aderir à essência das coisas, mas também de comandá-las.

Curioso endorsement a favor de uma língua capaz de reproduzir a estrutura do próprio referente, da parte de quem, como Rabelais, tinha usado o anagrama do próprio nome

\footnotetext{
4 "Voyez le Cratyle du divin Platon". Les Cinqu Livres de F. Rabelais, publiés avec des variantes et un glossaire, par P. Cheron. Paris: Librairies des bibliophiles, 1876. Livre IV: Pantagruel, p. 174.
} 
para assinar o romance. ${ }^{5}$ Não surpreende, portanto, que esta tese sobre a ligação metafísica entre res e verba, exposta no Quarto livro do ciclo, tenha uma clara contradição no Segundo livro, no episódio do encontro fatal entre Pantagruel e Panurge, que dali em diante será o coadjuvante da história. Uma espécie de clérigo vagante, maltrapilho e decrépito, atrás do aspecto do qual Pantagruel acredita reconhecer os traços de certa nobreza e sabedoria. Uma intuição que o gigante vê imediatamente confirmada pelo poliglotismo com o qual Panurge o surpreende. A ele se volta, na verdade, com um breve discurso pronunciado em doze línguas - árabe, hebraico, grego, latim, toscano, inglês, basco, baixo-bretão, holandês arcaico, espanhol, dinamarquês, baixo-alemão - do qual Pantagruel não compreende o significado, mas que não lhe deixa dúvidas sobre o fato de que a uma tal riqueza de códigos expressivos pode corresponder uma excepcional riqueza ou excelência de conteúdos. Mas aquele conteúdo se revela como o simples e humaníssimo pedido de ter a fome aplacada ${ }^{6}$.

$\mathrm{Na}$ Babel linguística demonstrada, Panurge, que sob a redundante multiplicação de sons revela uma mensagem elementar e trivial, faz, a partir do contraponto, uma língua universal, essencial, potente e originária (no episódio da luta contra os Andoilles também adâmica, mosaica, pitagórica) que Pantagruel demonstra compreender e que reconduz ao diálogo de Platão.

\footnotetext{
${ }^{5}$ Os primeiros dois livros do ciclo de Gargantua e Pantagruel (Les horribles et espoventables faictz et prouesses du très renommé Pantagruel Roy des Dipsodes, filz du Grand Géant Gargantua; e La vie très horrifique du grand Gargantua, père de Pantagruel, jadis composée par M. Alcofribas abstracteur de quintessence. Livre plein de Pantagruélisme) são publicados em Lion respectivamente em 1532 e em 1534 sob o pseudônimo de Alcobribas Nasier, que é o anagrama de François Rabelais.

${ }^{6}$ Les Cinqu Livres, cit., Livre II: Pantagruel, o diálogo entre Panurge e Pantagruel está no capítulo IX, p. 52-58.
} 
De um lado a convenção linguística multiplicada por doze gramáticas, que faz de Panurge um Hermógenes renovado, mas não por isso um sábio; de outro a universalidade de uma língua real, essencial, profética, que faz de Pantagruel e de qualquer um que a pratique - todos os falantes - potenciais adivinhadores.

Qual das duas posições reflete o pensamento de Rabelais? É Panurge ou Pantagruel o alter ego do autor?

Esta questão não é nova e obteve respostas diversas da parte de estudiosos excelentes: de Jules Michelet a Abel Lefranc, de Mikhail Bakhtin a Michel Foucault, de Marc Bloch a Lucien Febvre, de Étienne Gilson a Augustin Renaudet e Gianfranco Contini, até os mais recentes Michel A. Screech e Marie-Luce Demonet; respostas mais propensas a reconhecer em Rabelais, e, de forma mais ampla, no período do Renascimento, uma orientação anticonvencionalista e, coisa mais interessante, a assumir esta opção "naturalista" como um aspecto relevante aos fins da inserção do romance rabelaisiano e da cultura do Quattro e Cinquecento em uma incipiente modernidade ${ }^{7}$.

Para alguns, o realismo linguístico de Rabelais era uma reação à escolástica parisiense, empoleirada sobre as posições do terminismo ockhamista; para outros, era o apogeu da cultura popular e do sentimento medieval, ainda distantes - esta também é a tese de Lucien Febvre - de uma cultura burguesa, laica, científica, moderna ${ }^{8}$.

\footnotetext{
${ }^{7}$ A primeira edição russa foi publicada em 1965, ver: BAKHTIN, M. Rabelais and his World. Cambridge (Mss.); GILSON, E. "Notes médiévales au Tiers Livre de Pantagruel”. Revue d'Histoire Franciscaine, II, 1925; RENAUDET, A. Humanisme et Renaissance: Dante, Pétrarque, Standonck, Érasme, Lefèvre d'Étaples, Marguerite de Navarre, Rabelais, Guichardin, Giordano Bruno. Genève: Droz, 1958; SCREECH, M. A. Rabelais, Ithaca N.Y.: Cornell University Press, 1979; DEMERSON, G. Rabelais, une vie, une oeuvre, une époque. Paris: Balland, 1986. ${ }^{8}$ Cf. FEBVRE, L. Le probleme de l'incroyance au XVIe siècle. La réligion de Rabelais (1942). Paris: Edition Albin Michel, 1947. p. 363-366.
} 
Gostaria de me deter sobre este aspecto da relação entre questão linguística e "modernidade" propondo alguns episódios do romance que me parecem desmentir a hipótese de um realismo linguístico considerado por alguns intérpretes como absolutamente agostiniano ou anselmiano, e buscando visualizar, mesmo nessa opção que não definirei tout-court realista, os sinais de uma nova concepção do homem e da cultura, da qual Rabelais e, de forma mais geral, o humanismo italiano e europeu, participam.

Os termos de uma concepção teórica da língua, especificamente se relacionados a Rabelais, são problemáticos e por diversas razões.

O limite entre os personagens de Pantagruel e de Panurge - um está para o outro como apoio - tende assim a desvanecer também o ponto de vista do autor - nunca expresso em maneira direta - que se esconde indiferente atrás de um e outro personagem.

Por outro lado, é ainda mais complicado e equívoco extrair uma teoria linguística de uma obra que é por si mesma uma experimentação linguística, e que, como tal, é uma rediscussão de toda teoria consolidada. Rediscutir não por meio da proposta de paradigmas declaradamente irredutíveis aos precedentes, mas minando-os por dentro, com um comportamento que é ao mesmo tempo, e inevitavelmente, de compaixão e de intolerância, a ordem que mantém o conjunto e dá coerência àquela tradição e que - é somente caso de dizê-lo - é a mesma tradição da qual Rabelais e os seus personagens receberam a sua formação.

Também quando Rabelais, intelectual e humanista, se exprime como teórico da linguagem através da voz de seus personagens principais, o seu discurso é imediatamente 
alterado pelo eco do narrador Rabelais, militante da linguagem da qual faz um uso prático, de modo que até os elementos de uma eventual teoria são absorvidos e fagocitados entre o léxico, o estilo, e a própria intenção do relato. De veículo da narrativa, ou de objeto de uma teoria, a língua passa ao próprio conteúdo de uma narrativa cujas intenções cômicas, paródicas, desmistificadoras, impedem de dar sentido, uma interpretação, por assim dizer, definitiva, também àqueles enunciados expressos na forma de uma teoria ou de uma filosofia da linguagem.

A estas e outras ambiguidades próprias da escritura de Rabelais se juntam aquelas que acompanham a discussão quattro-cinquecentesca sobre a natureza da língua, às quais Rabelais faz alusão, seja para defendê-las, seja para ridicularizá-las, seja para uma e outra coisa ao mesmo tempo.

A questão não é apenas gramatical nem exclusivamente semiótica, mas remete a uma concepção especificamente filosófica e antropológica da linguagem enquadrada entre o contexto de uma 'filosofia civil' e de um humanismo definitivamente inclinado a refutar toda concepção abstratamente monumental na natureza humana.

Na cultura francesa do primeiro Cinquecento, a reflexão se complica ainda mais por causa da discussão sobre a ortografia fonética; uma discussão que procedia da constatação da lacuna entre escrita e pronúncia da língua vulgar e, portanto, da incoerência da ortografia francesa em relação à latina, e contava com um grupo aguerrido de apoiadores de uma reforma ortográfica voltada a introduzir símbolos alfabéticos diferentes daqueles latinos, diretamente relacionados aos sons. Para Jacques Dubois, Etienne Dolet, Guillaume des Autels, Henri Estienne, Louis Meigret, Jacques Peletier du Mans, se 
tratava de restabelecer a plena simetria entre símbolos alfabéticos e sons, defendida pelo De interpretatione aristotélico, mas com a explícita intenção de exaltar o usus e as potencialidades usagères do vernáculo francês.

Pelas necessidades mais gerais da vida e da conservação da paz entre os homens, união e concórdia duradoura - escrevia Maigret em seu Traité touchant le commun usage de l'escriture françoise - a natureza nos favoreceu dotando-nos de um meio mais útil que qualquer outro, a palavra9 .

Para restituir à palavra a eficácia esperada de modo a impor-se como instrumento iniludível da comunicação e da civilidade dos homens, não se tratava de renovar o fundamento ontológico dos símbolos linguísticos, mas antes de reconduzir a escrita à prolação e individuar uma nova scribendi ratio que não se fundamentasse apenas sobre princípios racionais (não sobre uma veritas in re, mas sobre uma veritas in animo ${ }^{10}$ ), mas que também exaltasse a conexão alfabeto-experiência de forma a propiciar uma linguagem aderente não à natureza das coisas, mas à natureza e às exigências dos homens.

Também em âmbito francês, existe um substancial acordo em sustentar que o ato linguístico - a voz - deriva da natureza; mas é igualmente evidente que não seja aquela faculdade expressiva compartilhada com os animais a fazer do homem o animal sermocinal. Parece ser ainda mais uma prerrogativa humana a atribuição àquelas vozes (sempre particulares, individuais) de vocabula, isto é, de símbolos e sinais significantes. Símbolos e sinais, os quais, enquanto se propagam

\footnotetext{
9 MEIGRET, L. Traité touchant le commun usage de l'escriture françoise. Paris: J. Longis, 1542. p. 64r.

${ }^{10}$ VALLA, L. Repastinatio dialectice ac philosophie. G. Zippel (Ed.). Padova: Antenore, 1982. I. p. 19.
} 
como "images des voix", fixam sons instáveis e subjetivos em uma imagem compartilhada, e por isso mesmo cheia de significado.

Entre os contemporâneos de Rabelais, as posições não são nem mesmo um pouco unívocas e unilaterais.

É verdade - como escreveu Foucault - que decola, na episteme do Renascimento, aquele efeito da ideia de um sinal divino sobre as coisas, uma semiótica universal que liga um significante a um significado por meio de uma "conjuntura" (isto é, uma semelhança ${ }^{11}$; mas também é verdade que não é menos difusa na cultura humanística a doutrina que, na esteira de Lorenzo Valla, defende a convenção linguística tornada significativa a partir do consenso da comunidade de falantes ${ }^{12}$ e busca a verdade e a eficácia da linguagem não em uma realidade externa ao sujeito, mas no juízo de quem se exprime, ao ponto de negar uma realidade objetiva, ou uma objetividade do real, se não nas dobras do discurso humano sobre o mundo. ${ }^{13}$ Mais ou menos com as mesmas palavras de Valla, Pantagruel, no capítulo XIX do Terceiro livro (1546) parece desmentir a opção cratiliana do episódio das Andouille: é um embuste dizer que existe uma linguagem natural. As línguas

\footnotetext{
11 FOUCAULT, M. Les Mots et les Choses, Archéologie des sciences humaines. Paris: Gallimard, 1966. p- 40-45.

12 VALLA, L. Repastinatio dialectice ac philosophie,. I, 14. G. Zippel (Ed.). Padova: Antenore, 1982, p. 122-23: «'Vox' humana naturalis illa quidem est, sed eius significatio ab institutione: que significatio et ipsa est qualitas.Verum et vox hec licet a natura oriatur, tamen ab institutione descendit. Homines enim, rebus cognitis, voces quas adaptarent invenerunt et propterea 'signa' appellaverunt, quorum primusfuit Adam,Deo auctore; easque cum suis significationibus posteros docuerunt, ut soni quidem sint a natura, voces autem sive signa et significationes ab artifice: atque ita, quod Plato vult, erit vox propria hominis. Aliter bruta non dicerentur 'muta' cum vocem emittant, sed quia non articulatam et artificio factam. Ex quo fit ut sonos auris, significationes animus, voces ambo percipiant».

${ }^{13}$ Cf. CAMPOREALE, S.; VALLA, L. Umanesimo e teologia. Firenze: Istituto Nazionale di Studi sul Rinascimento, 1972.
} 
se formam por instituições e por convenções arbitrárias entre os povos; as vozes (voix, voces) como as chamam os dialéticos, adquirem significado não pela natureza, mas à plaisir ${ }^{14}$.

Pantagruel em contradição consigo mesmo? Rabelais em contradição com Pantagruel? Rabelais em contradição consigo mesmo?

Provavelmente não. $\mathrm{Na}$ verdade, o problema, assim como o afrontam os humanistas e assim como o coloca também Rabelais por meio da dialética dos dois coadjuvantes $\mathrm{Pa}$ nurge e Pantagruel, não está simplesmente na opção 'convencionalista' contra o mito de uma linguagem veículo de uma verdade unilateralmente fundamentada na essência própria das coisas. Como para Valla, e também para Rabelais, dirimente e disruptivo não é o 'convencionalismo', mas a individualização, no usus loquendi, do critério da convenção linguística e da correta significância da palavra.

Não é um abstrato onomaturgo aquele que estabelece a relação significativa entre uma palavra e o seu referente, mas são os usuários daquela língua - um grupo historicamente e culturalmente definíveis - a estabelecer o código do qual e dentro do qual a palavra é objetivamente - isto é, historicamente, socialmente, publicamente, civilmente - significativa. É o valor de uso e não o ser fruto de uma convenção a propor-se como um aspecto de novidade e como veículo reformador. Mais que em uma filosofia da linguagem tal qual aquela de Valla e dos reformadores entre Quattro e Cinquecento, o contraste relativo às correntes nominalistas e terministas do século

${ }^{14}$ Cf. RABELAIS, F. Les Cinqu Livres, cit., Livre III: Pantagruel. Paris: Librairie des bibliophiles, 1876, p. 104: “C'est abus dire que ayons linguaiges naturel: les languaiges son par insitutions arbitraires et convenences des peuples; les voix, comme disent les dialecticiens, ne signifient naturellement, maismais à plaisir". 
precedente não é inferior em relação àquele existente nos confrontos dos propagadores de uma língua capaz de capturar a essência das coisas e, com aquela, referir uma verdade necessária, única, ontologicamente fundamentada.

Seria realmente impróprio reconduzir a questão da linguagem - assim como os humanistas a colocam - às categorias de nominalismo vs. realismo da quaestio de universalibus da escolástica, que de resto é um dos temas preferidos de Rabelais para reunir um registro cômico em muitos episódios da narrativa.

Talvez no próprio descarte que vem a se definir no Quattrocento italiano e, com alguns decênios de atraso, também no humanismo francês, entre categorias lógicas e categorias dialéticas, se deixam ler e resolver as aparentes contradições entre as posições assumidas pelos personagens de Rabelais. Enquanto a intenção dos lógicos é aquela de esclarecer em termos metafísicos a relação entre palavra, conceito e coisa, aquela que amadurece no âmbito das artes sermocinais busca pesquisar o fundamento humano das gramáticas para depois entregar a estas, pelo fato de ser veículo de um juízo de valor, tarefas não só comunicativas e classificatórias, mas também aquelas de uma renovada ars diiudicandi. A educação de Gargantua no Primeiro livro, as discussões dos sorbonagres ${ }^{15}$ (depois transformados em sofistas) às quais assiste Pantagruel, têm em mira aquela mesma propensão à hipostatização das qualidades separadas a partir de termos abstratos, contra as

\footnotetext{
15 Sorbonagre retorna no capítulo VIII da edição de 1533, Pantagruel. Les Horribles et espoventables faictz et prouesses du très renommé Pantagruel, roy des Dipsodes, filz du grand géant Gargantua, composez nouvellement par Maistre Alcofrybas Nasier, s. n., 1533; a partir da edição de '42, o termo não aparece e é substituído por sofistas; como por exemplo no capítulo XXI do Livre I, ed. cit., p. 75.
} 
quais é direta a crítica de Valla aos "transcendentais" - Ens, Aliquid, Unum, etc., ao conceito de essentia e, de forma geral, à mesa aristotélica de categorias e a todos aqueles termos e conceitos que não têm correspondentes na realidade ${ }^{16}$.

A desaprovação de Valla e o escárnio de Rabelais têm em vista a dissolução crítica daquilo que foi um dos maiores idola da filosofia e da teologia da baixa Idade Média: o espelhamento entre formas lógico-linguísticas de estruturas metafísico-ontológicas. Entretanto, embora aquela polêmica tivesse a própria radicação na querelle que, já no Duecento, tinha oposto ciceronianos e nominalistas, os defensores das $h u$ manae litterae aos fiéis seguidores do método lógico-especulativo escolástico, se reconduzida às categorias medievais, tem alguma coisa de paradoxal: nos encontraremos diante de um mestre de calambours e de construções semânticas no mínimo surreais (Rabelais) e do teórico do caráter artificial das gramáticas (Valla), os quais recuperam argumentos da tradição realista contra a logica modernorum e, sem perder com isso a sua carga inovadora e reformadora, contrastam e escarnecem mesmo aquela corrente terminista que tanta parte tinha tido no renovamento cultural do primeiro Trecento.

Um expert da tradição realista como Alexander Koyré advertiu contra julgamentos precipitados e anti-históricos: se o nominalismo tinha sido revolucionário ao início do século $\mathrm{XIV}$, era, ao contrário, conservador no século sucessivo, assim como o realismo, conservador já ao fim do século XII, se torna o símbolo de uma instância de renovação três séculos mais tarde. Para Koyré, esse é um dos tantos paradoxos da história

\footnotetext{
16 VALLA, L. Repastinatio dialectice et philosophie. T. I: "Retractatio totius dialecticae cum fundamentis universe philosophiae”. G. Zippel (Ed.). Padova: Antenore, 1982. p. 2; 15-16.
} 
das ideias. ${ }^{17}$ Ousarei dizer que é o efeito de uma antropologia alterada, que carrega consigo, inevitavelmente, um modo diverso de entender as prerrogativas humanas por excelência, linguagem e conhecimento; uma alterada - ou mutante - concepção do homem, que reflete segundo a própria perspectiva alterada, uma imagem diversa do mundo, de seus protagonistas, dos níveis de verdade que nele podem ser buscados com a mente e expressos com a palavra.

Nesta "reforma humanística" há espaço tanto para uma linguagem garantida pelo consensus hominum, quanto pelo reflorescer de línguas universais e de filologias simbólicas. É com a mesma postura reformadora e não em desacordo, ou ao menos, não em total desacordo, com as teses dos filólogos do Quattrocento, que se desenvolve, sempre em âmbito humanístico, a busca de uma língua perfeita a qual alude o elogio de Crátilo, no Livro Quarto de Rabelais. Não na convicção de restabelecer a coincidência entre essência metafísica e argumentação, mas no intuito, humanístico, de superar a linguagem capciosa e enganadora dos altercatores, de reagir ao proliferar de termos úteis às disputas dos lógicos, mas privados de qualquer referente voltando a uma significância originária. Uma língua materna - o hebraico de Postel ou a língua egípcia de Bruno - não porque metafísica ou teológica, mas porque originária; não anti-histórica, mas anterior, ou melhor, indiferente às divisões de uma filosofia contenciosa, abstrata, privada de um valor de uso. Também os números dos neopitagóricos, os símbolos dos cabalistas, os ícones e hieróglifos dos emblemáticos, se tornam a cifra de uma linguagem inefável, capaz

17 A. Koyré, De la mystique à la science: cours, conférences et documents, 19221962. P. Redondi (Ed.). Paris: École des Hautes Études en Sciences Sociales, 1986. Cit., p. 28-29. 
de sair da Babel de vozes sem sentido das escolas e de restaurar uma universalidade que não é o impossível retorno ao paraíso irreversivelmente perdido por Adão, mas que indica o projeto, orientado em direção a um tempo futuro, de construção de uma nova humanidade que, por meio da linguagem, da imperfeição, da aproximação, do pecado, da curiosidade, da fadiga, reformula o próprio destino.

E, de fato, a alocução convencionalista de Pantagruel no Terceiro livro - "as línguas se formam per convenção arbitrariamente" - tem um desfecho singular: se as palavras, os vocabula, são arbitrários, naturais, universais e verdadeiros são, ao contrário, os gestos, os sinais corpóreos ${ }^{18}$.

Neste ponto de sua narrativa, Rabelais, com um só movimento, põe em xeque tanto os ockhamistas quanto os defensores de uma língua inspirada. Inútil confiar nas respostas de oráculos e Sibilas - adverte Pantagruel - porque por meio dos equívocos e das anfibologias de suas palavras escritas ou proferidas, distanciam-se ainda mais da verdade que gostariam de desvelar. Melhor consultar um surdo-mudo de nascença, que jamais tenha dito ou ouvido uma palavra. Até porque, livre de toda influência verbal, a sua gestualidade seria compreendida por qualquer povo e em qualquer tempo; não carregaria qualquer ambiguidade interpretativa, seria clara ao ponto de não requerer consenso nem tradução porque é comum a todo o

\footnotetext{
${ }_{18}$ Esta é a conclusão: "Il demanda seulement un ioueur de farces, lequel il avoit veu on theatre, \& ne entendent ce qu'il disoit, entendoit ce qu'il exprimoit par signes et gesticulations: alleguant que soubs sa domination estoient peuples de divers languaiges, pour es quelz respondre et parler, luy convenoit user de plusieurs truchemens: il seul à tous suffiroit. Car en matière de signifier par gestes estoit tant excellent, qu'il sembloit parler des doigtz. Pourtant vous fault choisir un mut sourd de nature, affin que ses gestes et signes vous soient naifvement propheticques: non saincts, fardez, ne affectez. Reste encores sçavoir si tel advis voulez ou d'home ou de femme prendre" (Livro III, cit., p. 105).
} 
gênero humano. Gestos naturalmente proféticos - acrescenta ainda - não fingidos, artificiosos ou afetados.

Sobre esta preferência por um cratilismo ou de um naturalismo ou até de um realismo gestual, Rabelais, ao mesmo tempo teórico e experimentador, linguista e narrador, registra o acordo dos dois personagens.

E, entretanto, o gesto ao qual se refere Rabelais não é aquele de uma genérica língua marcada, mas de preferência a expressão de uma langue fisiológica, elementar, eventualmente também escatológica, universalmente eficaz não porque é gestual, mas porque é corporal. A transparência que o gesto reivindica não é relativa à coisa, à essência, à natureza daquilo de que se fala, e nem mesmo é relativa a um conceito, mas é a transparência em relação ao sujeito que fala, àquele que o discurso profere, à sua humanidade. E por isso é universal: porque restitui o parentesco não com as coisas, nem mesmo com o verbo que a criou, mas com a comunidade dos homens que aquele mesmo corpo compartilha. Então, eficaz e universal, porque está de acordo com a natureza humana, na sua imanência corpórea.

Os sinais do surdo-mudo são verdadeiros e não artificiais - como sublinha Pantagruel - porque exprimem sem outra intermediação o espírito daquele que fala, a essência não do objeto, mas do sujeito, uma veritas que não é in re, mas in animo.

Uma posição, esta, que não é nem aquela de Hermógenes nem aquela de Crátilo, nem dos ockhamistas nem dos realistas, mas que lembra muito de perto as reflexões linguísticas de Erasmo na Apologia de Latomo $^{19} \mathrm{e}$, mais indiretamente,

\footnotetext{
19 Para Erasmo, a linguagem tem o poder de revelar o espírito daquele que fala, de modo que os discursos malvados correspondem a um espírito corrupto, enquanto os verba vita são expressos por um espírito no qual Deus habita:
} 
as anotações de Valla: uma língua que permite conhecer nada além da mente e do coração daquele que fala, e que os faz conhecer ao coração e à mente de outros homens ${ }^{20}$.

Temos a confirmação em uma situação emblemática: a disputa entre Thaumaste e Panurge no Segundo Livro. Thaumaste é o douto inglês que chega a Paris, atraído pela fama de Pantagruel, para discutir com ele as mais altas questões filosóficas. Thaumaste não quer disputar com as palavras, como fazem os sofistas da Sorbonne, e nem mesmo por declamação, como os acadêmicos, nem por meio dos números como os Pitagóricos, nem à maneira de Pico nas suas Novecentas teses: "Quero disputar apenas por sinais, sem falar, porque a matéria é tão árdua que as palavras humanas não seriam suficientes para afrontá-lo como quero" 21 . Pantagruel consente, mas tendo "entrado em combustão" pela dificuldade da empresa, passa a vez a Panurge que aceita o desafio prometendo fazer o inglês "se cagar todo" 22 . E assim aconteceu. Thaumaste faz uma profusão de sinais - sobre os quais Rabelais não dá explicação, mas que podem parecer absolutamente sem sentido - aos quais Panurge responde alternando gestos que parecem igualmente insignificantes com outros muito mais claros - um dedo no nariz, o indicador da mão direita inserido e removido repetidamente do anel - o en-cycle - formado pelo polegar e

\footnotetext{
"Quemadmodum autem unicum illud Dei verbum imago est Patris, adeo nulla ex parte promenti dissimilis et eiusdem sit cum illo individuaeque naturae, ita humanae mentis imago quaedam est oratio", Apologia reiiciens quorundam suspiciones ac rumores natos ex dialogo figurato qui Jacobo Latomo... inscribitur. In: Desideri Erasmi. Opera omnia. Lugduni Batavorum, ${ }^{\star * \star} 1703$, vol. V, p. $772 f$. 20 VALLA, L. Retractatio, cit., 1, 2, 29-30, p. 19-20.

${ }^{21}$ RABELAIS, F. Le Cinqu Livres, cit., Livre II, p. 108: "Je veult disputer par signes seulement, sans parler, car le matieres sont tant arduës que les parolles humaines ne seroyent suffisantes à les expliquer à mon plaisir".

${ }^{22}$ Ibid., p. 110.
} 
pelo indicador da mão esquerda, arrotos, peidos, etc. São esses gestos inequívocos, os únicos que o público pode interpretar, que assinalam o êxito da disputa: prostrado pela contenda, "Thaumaste se levantou com dificuldade e levantando-se fez um grande peido de padeiro e mijou vinagre"23. Thaumaste se rende a Panurge - ao aluno que evidentemente não expressou nem a mínima parte da ciência do professor - e celebra a indiscutível superioridade daquele gigante de sabedoria que é Pantagruel: "vocês viram como um simples discípulo me contentou e me disse mais do que eu perguntei: me esclareceu muito, e ainda resolveu outras dúvidas inestimáveis. Posso assegurar-lhes que ele me abriu o verdadeiro poço e os abismos da enciclopédia quando em vez disso eu acreditava que não poderia ser para vocês um homem em condições de conhecer mais sobre seus primeiros elementos" 24 .

Rabelais põe em confronto uma dupla gestualidade: aquela eloquente e inequívoca dos peidos de Panurge, do suor de Thaumaste, dos sinais indecentes de uma semiótica expressiva e compartilhada, e aquela abstrata e não menos sofística da palavra, que os sorbonagres presentes na disputa interpretam nas maneiras mais inverossímeis, que nada têm a ver com as intenções de Panurge e do seu interlocutor. Uma gestualidade,

${ }^{23}$ Ibid., p. 120.

${ }^{24}$ Ibid., p. 120: "Vous avez veu comment son seul disciple me a contenté et mien a plus dict que n'en demandoys: d'abundand mia ouvert et ensemble solu d'aultres doubtes inestimables. En quoy je vous puisse asseurer qu'il mia ouvert le vray puits et abysme de l'encyclopedie, voire en une sorte que je ne pensoys trouver homme qui en sceust le premiers elemens seulement, c'est quand nous avons disputé par signes, sans dir mot, ny demi. Mais à temps je redigeray par escript ce que avons dict et resolu, affin que l'on ne pense que ce ayent esté mocqueries, et le ferait imprimer, à ce que chascun y apreigne, comme je ay faict. Donc povez juger ce que eust peu dire le maistre, veu que le disciple a faict telle prouesse, car non est discipulos super magistrum. En tous cas, Dieu soit loué! Et bien humblement vous remercie de l'honneur que vous avez faict à cest acte. Dieu vous le retribue eternellement!' 
a segunda, que resulta igualmente incompreensível e infundada, destituída como é de qualquer referente, totalmente autorreferenciada, como os "transcendentais" combativos de Valla, como as vanitates linguísticas daqueles sofistas, pretensiosos sábios, que Erasmo chama silenos ao contrário (ornados por fora, mas grosseiros e feios por dentro) ${ }^{25}$, como os termos abstratos das altercações sorbonistas ridicularizadas por Panurge. Com um acréscimo de insensatez em relação à palavra artificial e arbitrária: sua pretensão de corresponder à sublimitas de um referente metafísico: falo por sinais - tinha sustentado Thaumaste - porque as palavras humanas são muito imperfeitas para referir os mistérios da filosofia mais profunda, da cabala, da geomancia ${ }^{26}$.

Para Thaumaste, a potência dos sinais e a preferência que se conforma com uma língua marcada, derivam do caráter trans-humano que se ilude terem; referente e conceito gostariam de transcender - nas intenções do inglês - o plano da multiplicidade, da particularidade, da convenção e do arbítrio; plano no qual a "parole humaine" permanece, ao contrário, estavelmente colocada. Por isso o gesto seria chamado a superar não a parole mas sua origem humaine.

Aqui me parece estar o ponto: a derrota de Thaumaste, o ridículo no qual cai e ao qual Rabelais o compele está na pretensão, totalmente vã e ridícula, de "escalar o céu", de indagar, não menos que os metafísicos, as verdades últimas, as

${ }_{25}$ Apologia... Latomo, cit., vol. II, p. 772d: diferentemente dos Silenos de Alcebíades, figuras rústicas e brutas por fora, mas que continham um sublime deus dentro de si, os homens - segundo Erasmo - preferem o inverso, a saber, uma aparência elegante e ornada, que esconde um espírito corrupto e vazio. O vazio de sua linguagem, na aparência douta, mas na realidade sofística, lhes é um sinal característico.

${ }^{26}$ RABELAIS, F. Les Cinqu Livres, cit., Livre II, p. 107-108. 
formas eternas, isto é, aquilo que foge ao mundo da práxis, da história, do con-sensus hominum ${ }^{27}$.

Os sinais de Panurge, os mesmos aos quais, no fim, mais ou menos deliberadamente também se entrega Thaumaste, são inteiramente imanentes e corporais, fisiológicos mais do que obscenos, exatamente como são aqueles do surdo-mudo que se comunica com o outro sem a mediação da palavra e, por vezes, sem nem mesmo passar pelo abismo do conceito. Plenamente erasmiano, mas diria perfeitamente em linha com uma atitude humanística que experimenta a si mesma no Quattrocento italiano a partir de uma reflexão filosófica e antropológica de genere dicendi, a langue sans parole de Panurge é o espelho da natureza humana e ao mesmo tempo o meio através do qual um homem conhece o outro homem percebendo assim não a própria origem - divina ou natural - mas o próprio destino imanente e civil. E se considerarmos bem, o sucesso de Panurge não está tanto na capitulação de seu adversário, mas na capacidade persuasiva - se não demonstrativa - que os seus sinais revelam à presença de um auditório de teólogos, médicos, decretalistas, legisladores: propensos, do ínicio, às inferências absurdas para dar um significado à pletora dos gestos que veem executar os dois interlocutores, aceito no fim o sentido mais óbvio da discussão e começam a tapar o nariz depois que Thaumaste, por angústia, "se esmerdeava todo". Diante do "gros pet de boulanger" do derrotado ${ }^{28}$, cedem, eles mesmos, à linguagem do corpo: abandonam o

${ }^{27}$ Cf. VALLA, L. “De libero arbitrio”. In: Opera Omnia, cit., vol. I, p. 1.009.

${ }^{28}$ RABELAIS, F. Les Cinqu Livres, cit, Livre II, p. 16-17 : "Thaumaste, de grand hahan, se leva, mais en se levant fist un gros pet de boulangier, car le bran vint aprés, et pissa vinaigre bien fort, et puoit comme tous les diables. Les assistans commencerent se estouper les nez, car il se conchioit de angustie". 
círculo dos significados secretos de sua sabedoria sofística e aderem a um senso olfativo que não os trai e que une Panurge a Thaumaste em sua humanidade comum.

Não se equivocava Lucien Fébvre ao considerar Rabelais e a cultura renascentista que exprime, de uma parte uma concepção laica, burguesa, especializada, mas errava ao reconduzi-la ao sentimento medieval que se opõe à razão eletiva e seletiva dos modernos. Também Rabelais escolhe e escolhe Panurge, e por meio de Panurge escolhe uma humanidade efetiva, imperfeita, anti-heróica, filha do tempo e do pecado, capaz de enganar e de ser enganada, forasteira no mundo perfeito dos deuses como naquele ingênuo, das bestas, auge da consciência da própria fraqueza.

E realmente Panurge é o único personagem do romance de feitios plenamente humanos. E não é ao acaso que nele próprio, rústico e vulgar por fora, como um Sileno de Alcebíades, síntese das imperfeições humanas, filho de um humanismo inquieto, Rabelais esconde a cifra de uma humanidade não ideal, mas viva. Viva como Panurge, escreveu Primo Levi; viva porque procura, peca, goza e conhece ${ }^{29}$.

\section{Referências}

ALLEN, Michael J. B. Synoptic art: Marsilio Ficino on the history of Platonic interpretation. Florence Olschki, 1998.

ARISTOTELE. Della Interpretazione, a cura di M. Zanatta. Milano: Bur, 2001.

29 P. Levi, L'altrui mestiere. 
BACHTIN, M. Rabelais and his World. London: Cambridge, 1968.

CAMPOREALE, S., VALLA, L. Umanesimo e teologia. Firenze: Istituto Nazionale di Studi sul Rinascimento, 1972.

DEMERSON, G. Rabelais, une vie, une oeuvre, une époque. Paris: Balland, 1986.

ECO, Umberto. Diario mínimo. Milano: A. Mondadori, 1963.

FEBVRE,L. Le probleme de l'incroyance au XVIe siècle. Paris: Edition Albin Michel, 1947.

FOUCAULT, M. Les Mots et les Choses, Archéologie des sciences humaines. Paris: Gallimard, 1966.

GILSON, E. Notes médiévales au Tiers Livre de Pantagruel. In: Revue d'Histoire Franciscaine, II, 1925.

KOYRE, A. De la mystique à la science: cours, conférences et documents, 1922-1962. P. Redondi (Ed.). Paris: École des Hautes Études en Sciences Sociales, 1986.

LEVI, Primo. Laltrui mestiere. Torino: Einaudi, 1985.

MEIGRET, L. Traité touchant le commun usage de l'escriture françoise. Paris: J. Longis, 1542.

NASIER, Maistre Alcofrybas. Les Horribles et espoventables faictz et prouesses du très renommé Pantagruel, roy des Dipsodes, filz du grand géant Gargantua. C. Nourry, 1533.

PLATO. Opera. Tr. Marsilius Ficinus. Impr. Florence, S.A., 1484. 
RABELAIS, F. Les Cinqu Livres. Paris: Librairie des bibliophiles, 1876.

RENAUDET, A. Humanisme et Renaissance: Dante, Pétrarque, Standonck, Érasme, Lefèvre d'Étaples, Marguerite de Navarre, Rabelais, Guichardin, Giordano Bruno. Genève: Droz, 1958.

ROTERO, E. Apologia reiiciens quorundam suspiciones ac rumores natos ex dialogo figurato qui Jacobo Latomo. In: Desideri Erasmi. Opera omnia. Lugduni Batavorum, vol. V, 1703.

SCREECH, M. A. Rabelais. New York: Cornell University Press, 1979.

VALLA, L, Repastinatio dialectice ac philosophie. I, 14. G. Zippel (Ed.). Padova : Antenore, 1982. . De libero arbitrio. In: Opera Omnia. Vol. I. Florence: Polistampa, 2007. 